https://doi.org/10.15407/knit2019.04.048

UDC 504:37.03

O. Ulytsky, V. Yermakov, O. Lunova, O. Buglak

State ecology academy of postgraduate education and management, Kyiv, Ukraine

\title{
TECHNIQUE FOR ORTHOTRANSFORMED SATELLITE IMAGERY APPLICATION IN ENVIRONMENTAL ASSESSMENT
}

\begin{abstract}
The article solves an actual scientific and applied task, which is to form a methodological basis for the use of orthotransformed satellite imagery to create information services for environmental monitoring of objects of critical infrastructure. These services are designed to expand the capacity of the National Center for providing the information to central executive authorities about the results of environmental monitoring. The expansion involves the development of methods of using orthotransformed satellite imagery for the assessment of the environmental state. Based on the classification algorithm of enterprises and objects, a database of objects of critical infrastructure of Ukraine classified by their impact on the environment has been developed for the application in GIS-compatible systems. In the formation of the ideology of geographic information systems, the requirements for technical means are justified. These requirements include the deployed service, maintenance, filling and updating of the base of objects of critical infrastructure of Ukraine, the mechanism and order of visualization of impact assessments of all objects of the developed database. The algorithm has been adapted for application in an automated mode as part of GIS-systems. For research, the structure of the classifier using the state OCI register and validation of the developed methodology using the results of space imagery with specific examples for each of the objects of critical infrastructure of Ukraine has been developed. The following object is selected: Darnytsya Power Plant - an enterprise for the production and supply of electric and thermal energy. The study confirmed the relevance, scientific and practical value of using remote sensing methods for studying the ecological status of large areas of the earth's surface.
\end{abstract}

Keywords: environment, orthotransformed satellite imagery, potentially dangerous objects, database, objects of critical infrastructure.

\section{IINTRODUCTION}

In the conditions of scientific and technological progress, the relationship between society and nature is much more complicated. Man was able to influence the course of natural processes, began to master almost all available renewable and non-renewable natural resources, and as a result, to pollute and destroy the environment.

Pollution of the environment by wastes, emissions, sewage of all types of industrial production, agriculture, municipal services of cities has become global and put humanity on the brink of an ecological catastrophe.

(C) O. ULYTSKY, V. YERMAKOV, O. LUNOVA, O. BUGLAK, 2019
Modern activities of the society, for example, the construction of hydro-technical structures, mines, roads, wells, reservoirs, dams, construction of cities and other everyday aspects of human activity, already cause significant changes in the environment.

The main polluters of Ukraine are ferrous metallurgy (33\%), energy (30\%), coal (10\%), chemical and petrochemical industry (7\%). Every year, around 17 million tons of harmful substances are released into the atmosphere throughout Ukraine. More than onethird of all industrial emissions of harmful impurities in the air are found in heat stations that use fuel $[4,5]$.

Due to this state of the environment, namely the amount of pollutant emissions into the atmosphere 
by industrial, energy, transport and other objects, detailed information is needed about more than 24 thousand such objects (industrial enterprises, mines, quarries, main gas, oil and product pipelines, hydrotechnical structures, nodal railway stations, bridges, tunnels, storage facilities and industrial waste landfills, places for the preservation of hazardous substances, etc.) and the creation of a register of such facilities. The database (DB) of the registry must be constantly updated.

Specialists of the State Ecological Academy of Postgraduate Education and Management (hereinafter - the Academy) in the framework of the implementation of the scientific work "Development of the methodology for the application of orthotransformed satellite imagery for the assessment of the state of the environment" (state registration No. 0118U005460) planned updating of the database of potentially dangerous objects. Actualization involves analysis of the information made to it regarding the PDO, the determination of compliance with the PDO lists, the introduction of new data on PDO and the updating of existing PDO passport data changes, as well as the removal (blocking) of information in the Register database on objects that are officially recognized as those that are not PDO or liquidated.

For the updating of the DB of the Register, the data of PDO passports received from all enterprises, institutions, and organizations that have them in their subordination had been used.

Registration numbers are given to all objects, about which information is entered into the Register's database. The development of the PDO registry and its efficient use is ensured by an information system for the monitoring of the state of pollution control, based on the principles of maximizing the use of existing organizational structures of monitoring entities of the PDO and the unified state system of prevention and response to the environment (technonatural and natural) and the compatibility of technical, informational and the software of the monitoring entities used by them to perform the monitoring tasks of the PDO [8].

The PDO Registry software allows you to automatically search and retrieve information for more than 40 parameters that include the name of the object, the territorial location, the object category, type of activity, technical and economic characteristics, the type and category of hazard, the name and amount of hazardous substances and materials, etc., as well as combinations or separate parts of these parameters.

One of the strategic sources of state information on the state of natural resources, ecological monitoring of the Earth's surface, the determination of natural and man-made entities, etc. is the use of information systems with the introduction of modern technologies based on space remote sensing systems of the Earth.

The ultimate goal of remote sensing data processing is to recognize objects or situations that fall into the field of view and determine their position in space. But, since the shape, size, physical properties of objects are significantly different, methods of performing remote sensing procedures have been developed. Thus, to date, there is no single universal approach, suitable for the detection of all objects and situations $[9,10]$. Large-scale studies require the use of significant forces and funds both at the stage of field work and at the stage of analytical procedures. The use of data obtained during the decoding of aerial and space imageries in combination with the use of global satellite positioning devices (GPS) enables the effective detection and study of PDO objects, including objects of critical infrastructure (OCI) (these objects are incapacitated or the destruction of which threatens the national security, economy, health or safety of the population and which requires the attention and access of international experts for prevention of emergencies of ecological and man-made nature) by non-destructive methods under conditions of anthropogenic changes.

Widespread use of photogrammetric methods for object research was previously discouraged by the need to use sophisticated and expensive equipment used in cartography. At present, the situation is fundamentally changing due to the widespread use of digital cameras in field research and digital photogrammetric stations, GPS availability, and the development of relevant software for personal computers.

The modern world is very variable: cities are changing, new settlements appear, roads are being built, communication networks, engineering structures, new mining areas are being developed, forests 
are cut down, land use structures are changing. Therefore, there is always a need to update topographic maps.

As the primary material for topographic maps, aerial images have traditionally been used. Space digital images offer new opportunities: cheaper reshooting, increased area coverage and relief-related distortion.

Therefore, it is expedient to use the term environmental monitoring environment under which we will understand a comprehensive system of observations, estimates, and forecasts of changes in the state of emergency due to natural and man-made factors.

\section{RESEARCH OBJECTIVE}

The purpose of the work is to solve the actual scientific and applied task, which is to form a methodological basis for the use of orthotransformed satellite imagery to create information services for environmental monitoring of objects of critical infrastructure and expanding the capacity of the National Center for providing information to central executive authorities about the results of environmental monitoring based on space systems' data through the development of methods of using orthotransformed satellite imagery for the environmental assessment.

The subject of research - activities of objects of critical infrastructure and their impact on the environment.

The object of research is the process of contamination of the ecosystem by objects of critical infrastructure, business entities, owned or used by OCI, where hazardous substances can be used or manufactured, processed, stored or transported.

Research methods - theoretical and practical research methods are based on the application of a systematic approach to the use of GIS-analysis of cartographic modeling, system-structural analysis, and generalization.

\section{MATERIALS AND METHODS}

The technique for orthotransformed satellite imagery application in an environmental assessment of the relevant categories of objects of critical infrastructure of Ukraine on the state of the environment was formed at the following stages:
Orthophotomaps development. In the project work, the scheme indicates the location of the object, the number and nomenclature of sheets of scale $1: 10000$, covering the territory of the object, the total area of work, the number of sheets of orthophotomaps $1: 2000$, which is planned to be created. And it also provides a list of main types of work and regulatory documents, which take into account all types of work.

During the implementation of the research work, a technological scheme for the creation of orthophotomaps based on materials of space removal was developed (Fig. 1). The technology involves the following stages: preparatory, development of a project for the creation of orthophotomaps, the production of orthophotomaps, the collection (decoding) of information about potentially dangerous objects (PDO), the vectorization of contours of PDO, the production of orthophotomaps with the results of the vectorization of the contours of the PDO, placing of the results in the database for further analysis and use.

In addition, the preparatory phase includes:

- collecting the materials of topographic, geodetic, and cartographic security of the object with the compiled list of previously performed large-scale topographic surveys (catalogs of points of the SGN, topographic maps of different years of publication, materials of aerial surveys);

- raising archival materials of space imagery;

- analyzing the materials of topographic works performed earlier, making decisions about the relevance of the collected materials and the appropriateness of their further use;

- clarification of the task to perform work on the creation of orthophotomaps, as well as the boundaries of the site and the scale of future plans.

Database creation. In the process of implementing the orthophotomaps production phase, the following work should be performed:

- pre-processing of satellite imagery;

- construction of a geodetic survey network;

- scheduled attachment of satellite images;

- geometric correction of space imagery materials;

- direct orthophotomaps production;

- assessment of the accuracy of orthophotomaps.

Evaluation of the accuracy of the manufacture of orthophotomaps is performed by comparing the coordinates of control points, which are determined by 


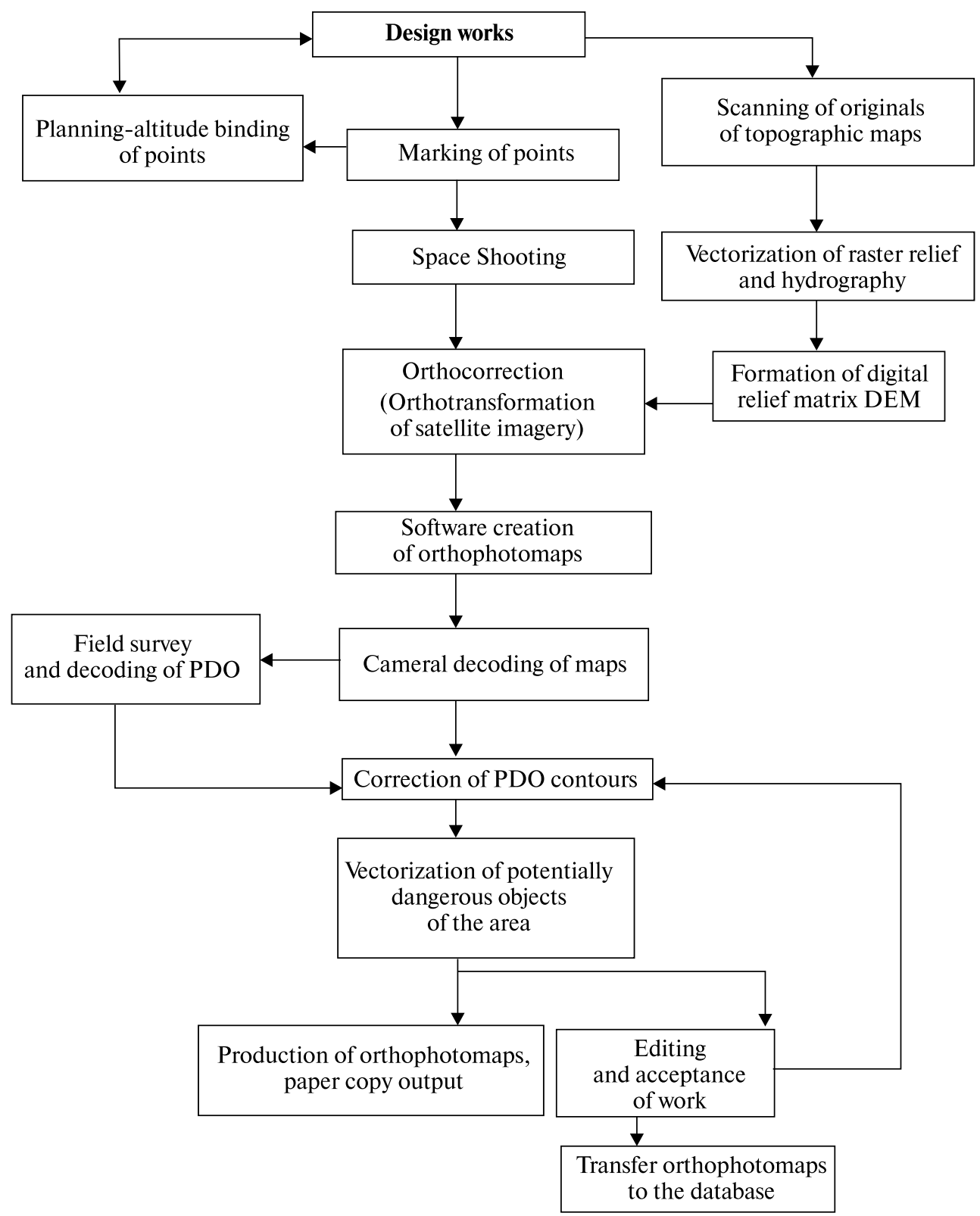

Fig. 1. Technological scheme of execution of work on creation of orthophotomaps on materials of space surveys

field methods and measured by the manufactured orthophotomaps.

The standard errors of the geometric correction are calculated by the formulas (1)-(5):

$$
\begin{aligned}
& V_{x}=X_{m}-X_{b}, \\
& V_{y}=Y_{m}-Y_{b},
\end{aligned}
$$

$$
\begin{aligned}
& m_{x}=\sqrt{\frac{V_{x}^{T} V_{x}}{n},} \\
& m_{y}=\sqrt{\frac{V_{y}^{T} V_{Y}}{n},} \\
& m_{s}=\sqrt{m_{x}^{2}+m_{y}^{2}},
\end{aligned}
$$


where $X_{m}, Y_{m}$ - vector of coordinates of points defined on orthophotomaps, $X_{b}, Y_{b}$ - vector of coordinates of points determined by geodetic methods, $V_{x}$, $V_{y}$ - vector of residuals in $X$ and $Y, m_{x}, m_{y}, m_{s}-$ standard errors of the geometric correction, $n-$ the number of control points.

The results of the evaluation of the accuracy of orthophotomaps creating are tabulated. An example of the results of assessing the accuracy of creating orthophotomaps is given in Table.

The orthophotomaps patches are executed according to the classification and nomenclature of topographic plans of scale $1: 2000$ in the corresponding task that is performed in the coordinate system shown in Fig. 2.

Database creation. The sources of incoming topographical data are: topographic and geodetic surveying materials, remote sensing data, topographic maps, digital map sets, reference and other materials, and data on terrain objects that have the correct probability, relevance, and accuracy. The output of the data acquisition system should be: sets of digital vector data, data sets of the digital model of relief, digital orthophotographs and orthophotomaps, which, after input control and processing, are loaded into the operational database of topographic data for further recording and accumulation in the database of topographic data.

Multitemporal analysis. Ukraine is characterized by a large population density and a rather high concentration of industrial and agricultural production. Therefore, it is necessary to carry out operational control of the ecological state of ecosystems, the load on which in some regions exceeds the ecologically acceptable limits. This is complicated by the negative impact on the nature of the consequences of the accident at the Chernobyl Nuclear Power Plant, as well as the risk of penetration of toxicants from the system of water - a breed in groundwater, which provides water supplies to $2 / 3$ of the country's settlements.

To solve the urgent problems of rational nature use, it is necessary to create modern means for ob-

Assessment of the accuracy of orthotransformation of space imagery materials

\begin{tabular}{|c|c|c|c|c|c|c|c|c|}
\hline Notes & $X_{m}, \mathrm{~m}$ & $Y_{m}, \mathrm{~m}$ & $X_{b}, \mathrm{~m}$ & $Y_{b}, \mathrm{~m}$ & $d X, \mathrm{~m}$ & $d Y, \mathrm{~m}$ & $d X^{2}, \mathrm{~m}$ & $d Y^{2}, \mathrm{~m}$ \\
\hline Reference & 319044.49 & 5582581.73 & 319044.42 & 5582581.87 & -0.07 & 0.14 & & \\
\hline$»$ & 319135.58 & 5579177.96 & 319135.79 & 5579177.96 & 0.21 & 0 & & \\
\hline$»$ & 318976.73 & 5581409.73 & 318977.08 & 5581410.57 & 0.35 & 0.84 & & \\
\hline$»$ & 317546.07 & 5581504.98 & 317546.28 & 5581504.7 & 0.21 & -0.28 & & \\
\hline$»$ & 316238.42 & 5580788.12 & 316238.5 & 5580787.56 & 0.08 & -0.56 & & \\
\hline$»$ & 315733.46 & 5576221.89 & 315734.37 & 5576222.03 & 0.91 & 0.14 & & \\
\hline$»$ & 313785.85 & 5577891.18 & 313785.77 & 5577891.18 & -0.08 & 0 & & \\
\hline$»$ & 318905.08 & 5578176.61 & 318904.73 & 5578177.34 & -0.35 & 0.73 & & \\
\hline$»$ & 317108.86 & 5579787.49 & 317108.79 & 5579787.35 & -0.07 & -0.14 & & \\
\hline Control & 319179.54 & 5582378.22 & 319179.37 & 5582378.64 & -0.17 & 0.42 & 0.0289 & 0.1764 \\
\hline$»$ & 319594.25 & 5579280.23 & 319594.75 & 5579279.95 & 0.5 & -0.28 & 0.25 & 0.0784 \\
\hline$»$ & 318943.65 & 5581239.08 & 318943.86 & 5581238.94 & 0.21 & -0.14 & 0.0441 & 0.0196 \\
\hline$»$ & 319661.73 & 5581365.18 & 319661.51 & 5581364.9 & -0.22 & -0.28 & 0.0484 & 0.0784 \\
\hline$»$ & 317515.14 & 5581369.65 & 317514.92 & 5581369.51 & -0.22 & -0.14 & 0.0484 & 0.0196 \\
\hline$»$ & 316288.85 & 5580669.25 & 316288.92 & 5580668.83 & 0.07 & -0.42 & 0.0049 & 0.1764 \\
\hline$»$ & 315561.84 & 5576273.41 & 315562.47 & 5576273.83 & 0.63 & 0.42 & 0.3969 & 0.1764 \\
\hline$»$ & 317058.51 & 5579763.7 & 317058.72 & 5579763.28 & 0.21 & -0.42 & 0.0441 & 0.1764 \\
\hline
\end{tabular}

$m_{x}=0.18 \mathrm{~m} ; m_{y}=0.65 \mathrm{~m} ; m_{s}=0.68 \mathrm{~m}$ 
taining operative information about the state of geosystems of Ukraine.

To implement the monitoring system of the PDO territories, the following tasks should be solved:

- to consider aerospace systems used during monitoring;

- to analyze methods of photogrammetric processing for the binding of different-time satellite imagery;

- to consider methods of automated decoding of digital satellite imagery;

- to develop an algorithm and method of bindings of different-time, various-scale images obtained by cameras of different types;

- to investigate the accuracy of bindings of different types of images;

- to develop a technological scheme of processing of various time-varying shots for monitoring of territories.

As an example, below fig. 3 provides a series of satellite imagery of DigitalGlobe to the territory of the Darnytsya combined heat and power plant emission site during 2004-2017.

ArcGIS integration. The system for obtaining data includes external executors using different means of informatization in order to produce input sets of topographical data that are submitted to the entrance of the database.

The sources of incoming topographical data are: topographic and geodetic surveying materials, remote sensing data, traditional topographic maps, digital map sets, reference and other materials, and data on terrain objects that have the correct probability, relevance, and accuracy. The output of the data acquisition system should be: sets of digital vector data, data sets of the digital relief model, digital orthophotographs and orthophotomaps, which, after input control and processing, are loaded into the operational database of topographic data for further recording and accumulation in the database repository. The conceptual unity of the database is achieved through the integrated implementation of the basic provisions and requirements of a series of international standards ISO 19100 according to the methodology of open systems standards profiling.

Environmental impact assessment. Analysis and decoding of objects in satellite imagery are sequentially

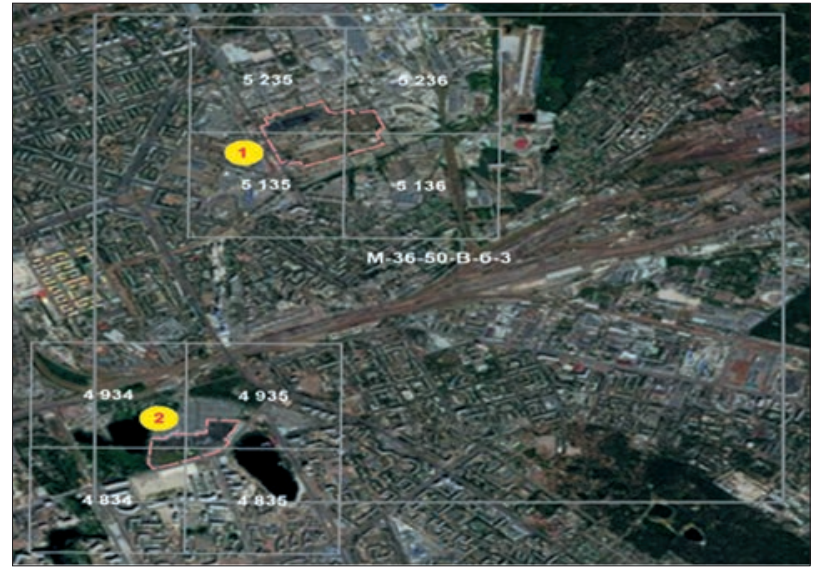

Fig. 2. Scheme of orthophotomaps patches

performed steps. At the stage of analysis, the scene is rendered, and the image is segmented with the identification and localization of objects [2], which may be of interest from the point of view of solving a general task (actualization of cartographic information can be an example of a common similar task).

When decoding, objects recognition tasks and their interpretation are solved [1, 3]. When an object is recognized, it is assigned to one of the classes (types), the list of which is usually given. For example, in topographic decoding, the list of classes can be set on the basis of the heading of the Classifier of topographic objects. The assignment of an object to a particular class is carried out as a result of visual or machine analysis and evaluation of its defining features.

When interpreting, on the basis of the revealed information, the state of the objects is assessed, and also some prediction of the development of events and processes can be made. When decoding objects and landscape elements, their geometric and spectral characteristics (direct decoding features), as well as interconnection and interdependence of natural and anthropogenic objects (indirect features) are used [3, 7, 9, 10].

Software implementation. Launching of new international scientific and commercial medium and high resolution remote sensing satellite systems such as EOS, IRS, SPOT, Ikonos, QuickBird, OrbView, GeoEye, EnviSat, as well as Leica ADS40 digital imaging systems, ZI Imaging DMC, Applanix DSS, Merrik DACS, Vexcel UltraCam D, ITRES CASI, Wehrli 3-DAC-1 and the like leads to the need to create and upgrade a ground-based digital data acquisi- 


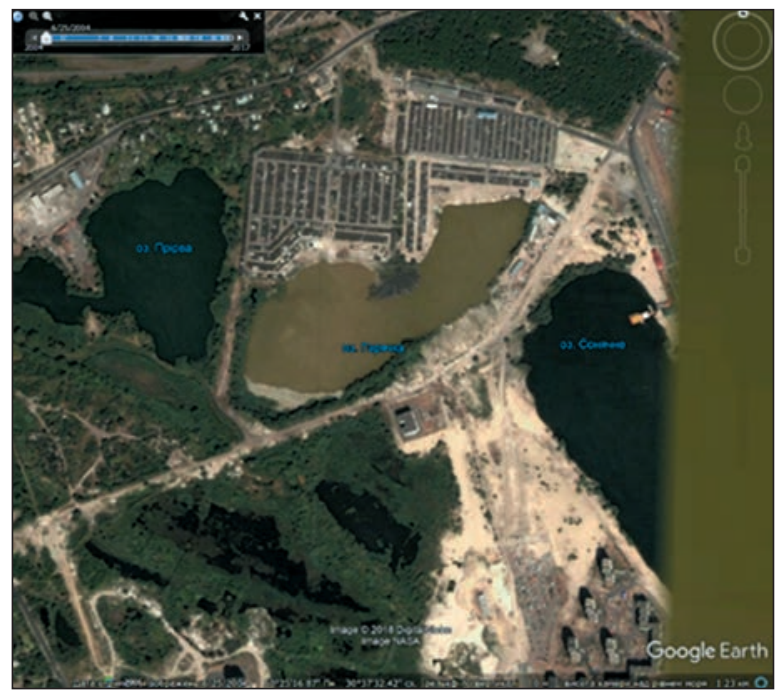

2004

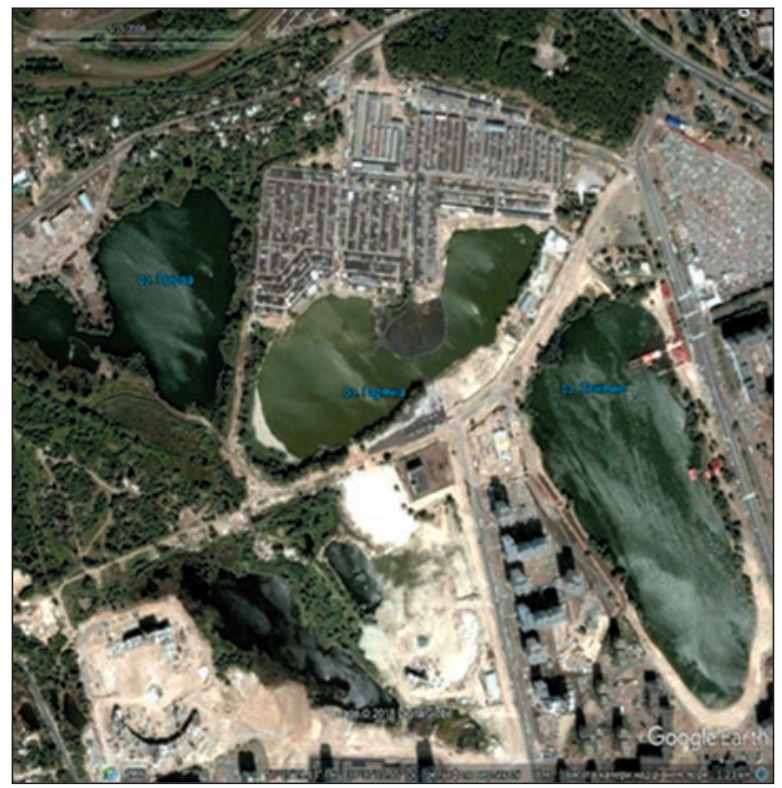

2008

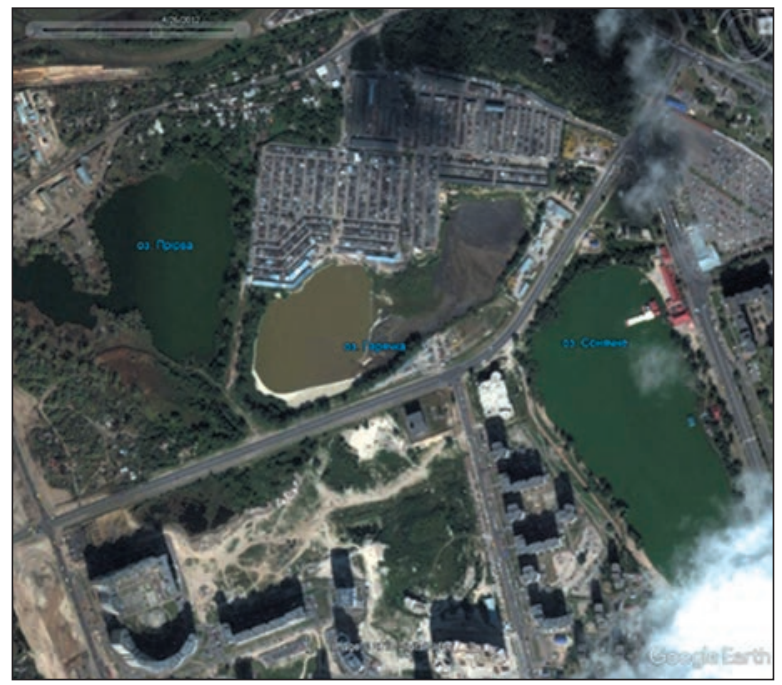

2012

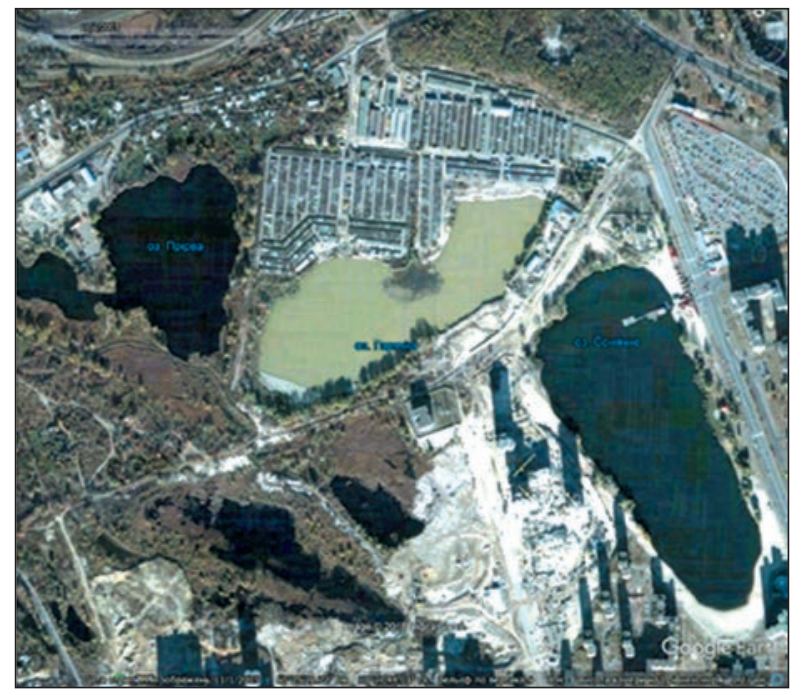

2005

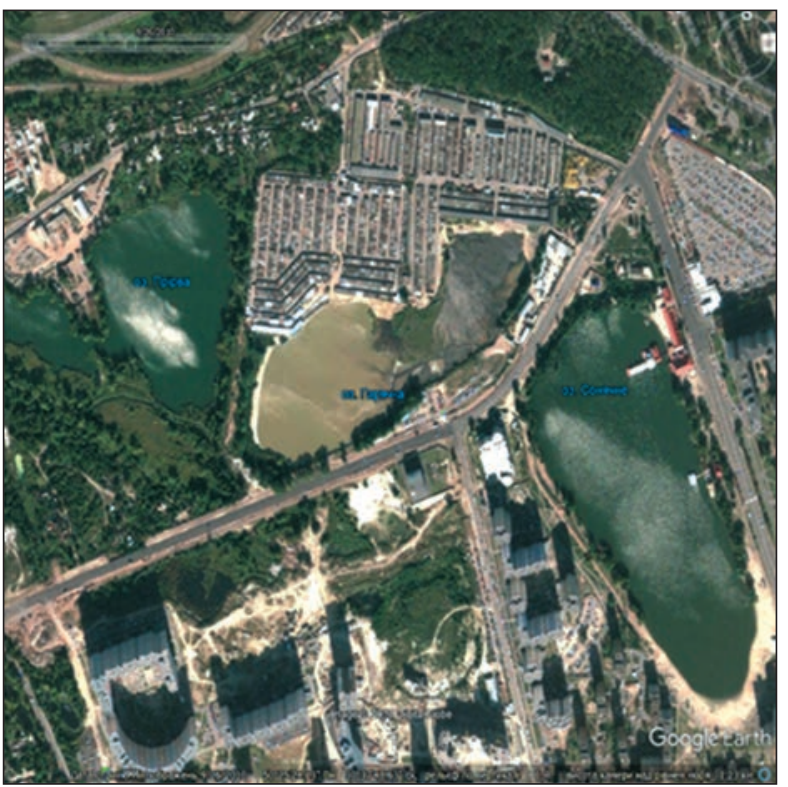

2010

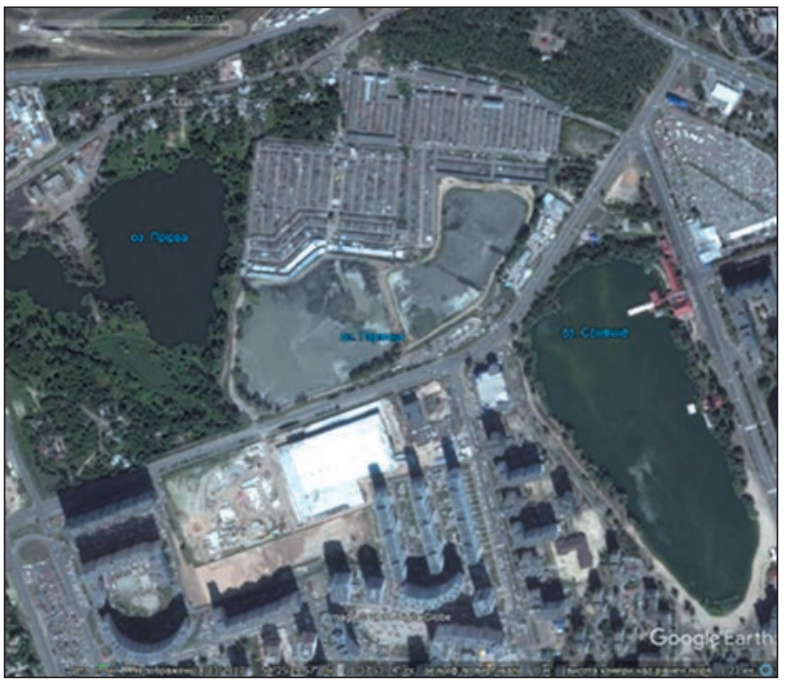

2017

Fig. 3. Satellite imagery of the territory of the emissions area of the Darnytsya combined heat and power plant during 2004-2017 years 
tion system for remote sensing and air surveillance, which in turn entails an increasing role of processing software derived from digital satellite imagery [2].

Thus, today's remote sensing data processing software enables the creation of complete technological chains of digital processing of satellite imagery for solving known thematic tasks, ranging from radiometric correction of off-board bitmap images and finishing with the publication of the resulting vector thematic maps [6].

\section{RESULTS OF WORK}

- The algorithm of classification of enterprises and objects of critical infrastructure of Ukraine by industries and their influence on the environment is developed: atmospheric air, soils, underground and surface waters, forest resources and nature reserve fund.

- Based on the above-said algorithm of classification, a system compatible with GIS-systems has been developed, classified according to their influence on the environment of objects of critical infrastructure of Ukraine.

- A method of using the orthotransformed satellite imagery for the estimation of the impact of the relevant categories of objects of critical infrastructure of Ukraine on the state of the environment is proposed.

\section{CONCLUSIONS}

Launching of new international scientific and commercial medium and high resolution remote sensing satellite systems such as EOS, IRS, SPOT, Ikonos, QuickBird, OrbView, GeoEye, EnviSat, as well as Leica ADS40 digital imaging systems, ZI Imaging DMC, Applanix DSS , Merrik DACS, Vexcel UltraCam D, ITRES CASI, Wehrli 3-DAC-1, and similar leads to the need to create and improve a terrestrial digital data acquisition system for remote sensing and aerial surveillance of the state of the environment, which in turn entails the growth of the role of the software for using aerospace obtained digital images and getting orthotransformed satellite imageries.

The proposed remote sensing data processing software will allow the creation of completed technological chains of digital processing of satellite imagery for solution of thematic tasks, ranging from radiometric correction of off-board bitmap images, the use of orthotransformed space imageries to assess the impact of the relevant categories of critical infrastructure objects of Ukraine on the state of the environment, and ending with the publication of the resulting vector thematic maps.

Thus, the method developed during the implementation of the scientific work can be validated using the results of space surveys on concrete examples for each class of objects of critical infrastructure of Ukraine.

\section{REFERENCES}

1. Dobrovolskyy V. V. (2005). Fundamentals of the theory of ecological systems. Textbook. Kyiv: Professional, 272 p. [in Ukrainian].

2. Dzhygyrey V. S. (2007). Ecology and environmental protection. Textbook. Kyiv: Znannya, 422 p. [in Ukrainian].

3. Lavryk V. I. (2002). Methods of mathematical modeling in ecology. Kyiv, Publ. house «KM Academy», 203 p. [in Ukrainian].

4. Lysychenko G. V., Zabulonov Ju. L., Khmil G. A. (2008). Natural, man-made and environmental risks: analysis, evaluation, management. Kyiv: Nauk. Dumka, 542 p. [in Ukrainian].

5. Malymon S. S. (2009). Fundamentals of ecology. Textbook. Vinnytsya: Nova Knyga, 240 p. [in Ukrainian].

6. Maslov V. P. (2005). Physical and technological problems of ensuring the operability of optoelectronic sensor devices under extreme conditions. Sensory electronics and microsystem technology, No. 1, 57-62 [in Russian].

7. Talanchuk P. M., Golubkov S. P., Maslov V. P., et al. (1991). Sensors in the control and measurement technology. Kiev: Tekhnika, 175 p. [in Russian].

8. Ulytsky O. A., Yermakov V. M., Bondar O. I. (23.10.2017). Report on implementation scientific work 0117U006967 on 23.10.2017. Conducting assessment and study of the ecological and technogenic state of Donetsk and Luhansk regions with the purpose of developing recommendations on natural resource restoration on ecological grounds [in Ukrainian].

9. Verkhovtsev V. V. (2005). Applied (prospecting and engineering-geological) aspects of the study of platform geostructures of Ukraine. Environmental ecology and life safety, No. 3, 80-92 [in Russian].

10. Verkhovtsev V. N. (2007). The latest platform geostructures of Ukraine and the dynamics of their development. Dissertation of the doctor of geological sciences. Kiev, 423 p. [in Russian].

Received 21.01.2019 
О. А. Улицький, В. М. Срмаков, О. В. Луньова, О. В. Буглак

Державна екологічна академія

післядипломної освіти та управління,

Київ, Україна

\section{МЕТОДИКА ЗАСТОСУВАННЯ ОРТОТРАНСФОРМОВАНИХ КОСМІЧНИХ ЗНІМКІВ ДЛЯ ОЦІНКИ СТАНУ НАВКОЛИШНЬОГО СЕРЕДОВИЩА}

В статті розв'язано актуальну науково-прикладна задачу, що полягає у формуванні методологічного базису застосування ортотрансформованих космічних знімків для створення інформаційних сервісів з екологічного моніторингу стану об'єктів критичної інфраструктури та розширення можливостей Національного центру із забезпечення центральних органів виконавчої влади інформацією про результати екологічного моніторингу на основі даних космічних систем за рахунок розробки методики застосування ортотрансформованих космічних знімків для оцінки стану навколишнього середовища. На основі алгоритму класифікації підприємств та об'єктів критичної інфраструктури України розроблено сумісну з GIS-системами базу класифікованих за їхнім впливом на природне середовище об’єктів критичної інфраструктури України та розроблено методику застосування ортотрансформованих космічних знімків для оцінки впливів відповідних категорій об'єктів критичної інфраструктури України на стан природного середовища. При формуванні ідеології геоінформаційних систем обгрунтовано вимоги до технічних засобів, на яких має бути розгорнуто сервіс, порядку ведення, наповнення та оновлення бази об’єктів критичної інфраструктури України, механізму та порядку візуалізації оцінок впливів усіх об'єктів розробленої бази на основі GIS-систем. Проведено адаптацію алгоритму для застосування в автоматизованому режимі у складі геоінформаційної системи. Для цього в рамках досліджень розроблено структуру класифікатора з використанням державного реєстру ПНО та валідацію розробленої методики з використанням результатів космічної зйомки на конкретних прикладах для кожного з класу об'єктів критичної інфраструктури України. За об’єкт господарської діяльності обрано Дарницьку ТЕЦ - підприємство 3 виробництва та постачання електричної та теплової енергії. В рамках дослідження підтверджено актуальність, наукову та практичну цінність використання дистанційних методів дослідження екологічного стану великих територій земної поверхні.

Ключові слова: навколишнє природне середовище, ортотрансформовані космічні знімки, потенційно небезпечні об'єкти, база даних, об’єкти критичної інфраструктури.

\section{О. А. Улицкий, В. Н. Ермаков, О. В. Лунева, А. В. Буглак}

Государственная экологическая академия последипломного образования и управления, Киев, Украина

\section{МЕТОДИКА ПРИМЕНЕНИЯ ОРТОТРАНСФОРМИРОВАННЫХ КОСМИЧЕСКИХ СНИМКОВ ДЛЯ ОЦЕНКИ СОСТОЯНИЯ ОКРУЖАЮЩЕЙ СРЕДЫ}

В статье решена актуальная научно-прикладная задача, которая заключается в формировании методологического базиса применения ортотрансформированных космических снимков для создания информационных сервисов по экологическому мониторингу состояния объектов критической инфраструктуры и расширения возможностей Национального центра по обеспечению центральных органов исполнительной власти информацией о результатах экологического мониторинга на основе данных космических систем за счет разработки методики применения ортотрансформированных космических снимков для в оценки состояния окружающей среды. На основе алгоритма классификации предприятий и объектов критической инфраструктуры Украины разработана совместимая с GIS-системами база классифицированных по их влияниям на природную среду объектов критической инфраструктуры Украины и разработана методика применения ортотрансформированных космических снимков для оценки воздействия соответствующих категорий объектов критической инфраструктуры Украины на состояние природной среды. При формировании идеологии геоинформационных систем обоснованы требования к техническим средствам, на которых должен быть развернут сервис, порядок ведения, наполнения и обновления базы объектов критической инфраструктуры Украины, механизм и порядок визуализации оценок воздействий всех объектов разработанной базы на основе GIS-систем. Проведено адаптацию алгоритма для применения в автоматизированном режиме в составе геоинформационной системы. Для этого в рамках исследований разработана структура классификатора с использованием государственного реестра ПОО и валидация разработанной методики с использованием результатов космической съемки на конкретных примерах для каждого из класса объектов критической инфраструктуры Украины. В качестве объекта хозяйственной деятельности выбрана Дарницкая ТЭЦ - предприятие по производству и поставке электрической и тепловой энергии. В рамках исследования подтверждена актуальность, научную и практическую ценность использования дистанционных методов исследования экологического состояния крупных территорий земной поверхности.

Ключевые слова: окружающая естественная среда, ортотрансформированные космические снимки, потенциально опасные объекты, база данных, объекты критической инфраструктуры. 